\title{
Structural and functional failure of fibrillin-1 in human diseases (Review)
}

\author{
SANDRA SCHRENK ${ }^{1}$, CAROLA CENZI $^{1,2}$, THOMAS BERTALOT $^{1}$, \\ MARIA TERESA CONCONI ${ }^{1,3}$ and ROSA DI LIDDO ${ }^{1,3}$
}

\begin{abstract}
${ }^{1}$ Department of Pharmaceutical and Pharmacological Sciences, School of Medicine, University of Padova, I-35131 Padova; ${ }^{2}$ Department of Chemistry and Technology of Drugs, School of Pharmacy and Medicine, Sapienza University of Rome, I-00185 Rome; ${ }^{3}$ Foundation for Biology and Regenerative Medicine,

Tissue Engineering and Signaling ONLUS, I-35030 Padova, Italy
\end{abstract}

Received September 7, 2017; Accepted November 29, 2017

DOI: $10.3892 /$ ijmm.2017.3343

\begin{abstract}
Fibrillins (FBNs) are key relay molecules that form the backbone of microfibrils in elastic and non-elastic tissues. Interacting with other components of the extracellular matrix (ECM), these ubiquitous glycoproteins exert pivotal roles in tissue development, homeostasis and repair. In addition to mechanical support, FBN networks also exhibit regulatory activities on growth factor signalling, ECM formation, cell behaviour and the immune response. Consequently, mutations affecting the structure, assembly and stability of FBN microfibrils have been associated with impaired biomechanical tissue properties, altered cell-matrix interactions, uncontrolled growth factor or cytokine activation, and the development of fibrillinopathies and associated severe complications in multiple organs. Beyond a panoramic overview of structural cues of the FBN network, the present review will also describe the pathological implications of FBN disorders in the development of inflammatory and fibrotic conditions.
\end{abstract}

\section{Contents}

1. Introduction

2. FBN network assembly and elastogenesis

3. Non-elastic components of the FBN network

4. FBN matrix: A dynamic deposit of growth factors

5. Cellular sensing of FBN signalling

6. FBN diseases in humans

7. In vitro and in vivo studies of $\mathrm{FBN}$ assembly

Correspondence to: Professor Rosa Di Liddo, Department of Pharmaceutical and Pharmacological Sciences, School of Medicine, University of Padova, 5 Via Marzolo, I-35131 Padova, Italy

E-mail: rosa.diliddo@unipd.it

Key words: fibrillin, elastic fibres, extracellular matrix, fibrosis, connective tissue disease
8. FBN-1 involvement in inflammatory disorders

9. Gut-FBN axis

10. Conclusions and perspectives

\section{Introduction}

Fibrillin (FBN)-1 is a calcium-binding protein that assembles to form 10-12 nm microfibrils in the extracellular matrix (ECM) of elastic and non-elastic tissues. The human gene FBN-1 spans $>230 \mathrm{~kb}$ (1) on chromosome 15q15-21.1 (2) and is highly fragmented into 65 exons. The primary protein structure reveals multi-domains (3), which primarily consist of epidermal growth factor (EGF)-like and certain other modules (4). Out of a total of 47 EGF domains (5), 43 modules contain the calcium binding (cbEGF) consensus sequence D/N-XD/ $\mathrm{N}-\mathrm{E} / \mathrm{Q}-\mathrm{Xm}-\mathrm{D} / \mathrm{N}-\mathrm{Xn}-\mathrm{Y} / \mathrm{F}$ (6), which provides structural stabilization (7), a characteristic rigid rod-like shape (8-10) and protection against proteolysis (11), and allows the control of self- or FBN-2-interaction $(12,13)$ and interactions with ECM components, including fibulin-2, heparin/heparan sulphate and microfibril-associated glycoprotein (MAGP)-1 (14-17). Disulphide bonds formed among the six cysteine residues in EGF and cbEGF, in a C1-C3, C2-C4 and C5-C6 pattern (9), contribute to further stabilize FBN-1. EGF-like domains are interspersed by seven transforming growth factor (TGF)- $\beta$ binding protein (TB)-like modules and structurally related latent TGF- $\beta$-binding proteins (LTBPs) (18). Characterized by eight cysteine residues that form four disulphide bonds (C1-C3, C2-C6, C4-C7 and C5-C8 arrangement), TB domains occur seven times in FBN-1. Among them, the fourth TB module is of particular interest due to the presence of the cell binding site RGD (arginine-glycine-aspartic acid), which mediates interactions with integrins (19). Additionally, as with other FBNs, 'hybrid domains' are repeated twice in FBN-1 and are stabilized by four intradomain disulphide bonds in a C1-C3, $\mathrm{C} 2-\mathrm{C} 5, \mathrm{C} 4-\mathrm{C} 6$ and $\mathrm{C} 7-\mathrm{C} 8$ formation (20). The unique $\mathrm{N}$ - and C-terminal domains of FBN-1 include four and two cysteine residues, respectively, and contain the basic consensus sequence for processing by furin-type enzymes (21-23). A distinguishing feature of FBN-1 is the presence of a proline-rich domain close 
to its $\mathrm{N}$-terminus $(4,24)$. A summary of the chromosomal location, domain organisation and primary functions of FBN-1 is presented in Fig. 1.

\section{FBN network assembly and elastogenesis}

FBN-1 is synthesized as an $\sim 350 \mathrm{kDa}$ precursor molecule, profibrillin-1, which requires proteolytic processing by furin proteases into its biologically active form $(\sim 320 \mathrm{kDa})$ prior to incorporation into microfibrils $(22,25)$. Accounting for all microfibril structural features, FBN alignment models predict the initial interactions between the $\mathrm{N}$ - and C-terminal sequences, which cause a head-to-tail alignment and an approximate one-third stagger that is stable as a $56 \mathrm{~nm}$ folded form (26-28). FBN bundles are stabilized by transglutaminase-derived cross-links (29). Microfibril assembly has been reported to be dependent and fine-tuned by a variety of FBN-associated proteins. When visualized by rotary electron microscopy (30), the extracted microfibrils exhibit a beaded string morphology with dark areas, which are termed 'bead' regions and appear in an average periodicity of $56 \mathrm{~nm}$ (31). Highlighting their important structural role, FBN microfibrils are essential for the process of elastogenesis, acting as a scaffold for the soluble precursor of elastin (tropoelastin) (32). Tropoelastin molecules are secreted and deposited extracellularly onto a preformed, organized FBN microfibril network, which gives rise to mature, elastic fibres that are subsequently processed by the lysyl oxidase enzyme for the formation of desmosine cross-links. The importance of FBN in the formation of elastic fibres is highlighted by the inability of FBN-1 knockout mice to form functioning elastic fibres, in addition to a disorganization of elastic fibres (33) and a reduction of tissue flexibility and extensibility, primarily in the arteries, lungs, skin and other dynamic connective tissues (17). Unlike cbEGF-cbEGF, EGF1-EGF2 and TB6-cbEGF32 are flexible domain interfaces $(34,35)$.

\section{Non-elastic components of the FBN network}

FBN microfibrils interact with a large variety of ligands. The binding with ECM components involves the C-terminal regions of FBNs (36) and is essential for regulating protein assembly and functionality. Depending on the cell type, the FBN network (36-39) and MAGP (40-42) contribute to microfibril biogenesis. Additionally, fibulin-2 appears to colocalise with microfibrils in certain tissues at the interface between microfibrils and elastin (14). Fibulin-2 specifically binds to the N-terminal region of FBN-1, while it also interacts with fibronectin and exhibits a connecting role with other ECM molecules. As with fibulin-2, fibulin-1 localizes with elastin providing connective bridges to other ECM components and to cells through laminin, fibronectin, nidogen or fibrinogen (43). Contributing to elastic fibre assembly, fibulin-5 interacts with FBN and tropoelastin (44). According to experimental data, fibulin-5 null mice exhibit structural abnormalities due to disrupted elastogenesis $(45,46)$. As they may be absent in tissues exerting strong tensional forces, such as tendons, fibulins are associated with elastic fibre assembly rather than the mechanical properties of microfibrils. Furthermore, studies have demonstrated that A disintegrin-like and metalloprotease (reprolysin-type) with thrombospondin type-1 motif (ADAMTS) and ADAMTS-like (ADAMTSL) proteins, including ADAMTSL4 (47), ADAMTSL6 (48) and ADAMTSL10 (49), bind to FBN and modulate microfibril assembly $(49,50)$. If mutations occur in these genes, pathologies similar to fibrillinopathies are observed. Direct interaction of FBN with various proteoglycans are reported to be essential for network assembly and the maintenance of basement membranes $(51,52)$. The proteoglycans decorin and biglycan are able to bind to tropoelastin, while only decorin directly interacts with FBN-1 (41,53). However, biglycan forms a ternary complex with tropoelastin and MAGP-1, indicating a potential role during elastogenesis (53). Notably, alterations in decorin expression have been observed in neonatal Marfan syndrome, which is connective tissue disorder $(54,55)$. The heparan sulphate proteoglycan (HSPG) perlecan, also termed HSPG-2, colocalises with FBN and elastin (56), and binds to the central region of FBN-1 (57). Additionally, these HSPGs bind to cell surface molecules and growth factors (58), such as basic fibroblast growth factor, indicating an indirect involvement of FBN in the regulation of cell functions and stem cell niches $(59,60)$. The chondroitin sulphate proteoglycan versican controls the genesis of elastic fibres $(61,62)$ and acts as a key factor in inflammation by interacting with the adhesion molecules of activated leukocytes, including L-selectin, CD44 and chemokines, to recruit inflammatory cells $(63,64)$. FBN-associated collagen with interrupted triple helices type XVI is associated with microfibrils in various tissues, including the upper papillary dermis (65) and dorsal root ganglia (66), indicating a potential association between FBN assembly and neuronal regeneration. LTBPs interact with FBN at the N-terminal region $(16,67)$ while they are also anchored to other ECM components, such as fibronectin (68-70). These interactions are important in regulating the availability and the activation of TGF- $\beta$ deposited in the ECM. LTBP 1,3 and 4 covalently bind to the small latent TGF- $\beta$ complex with their third TB domain and control the local TGF- $\beta$ bioavailability (71). In addition to TGF- $\beta$ via LTBPs, a number of bone morphogenetic proteins (BMPs), and growth and differentiation factors, directly bind to FBN at the N-terminal region (72-75). Furthermore, through the RGD binding site in the TB4 domain, FBN-1 interacts with different integrins that are responsible for cell-matrix communication.

\section{FBN matrix: A dynamic deposit of growth factors}

The FBN network is an important constituent of connective tissues that interacts with the cellular compartment. It controls the bioavailability and activity of the TGF- $\beta$ superfamily, which activates specific cellular signalling pathways for preserving tissue homeostasis. The loss of cell matrix interactions is a factor implicated in the pathological manifestations observed in microfibrillinopathies (Fig. 2). By indirect interaction with FBN through LTBPs, as with TGF- $\beta$, or direct interaction, for example BMPs (76), growth factors regulate the cellular behaviour and control cell survival, differentiation and response to injury (77). TGF- $\beta$ isoforms (TGF- $\beta 1,2$ and 3) are synthesized as precursor proteins that comprise a growth factor domain at the C-terminal end and a latency-associated peptide (LAP) at 


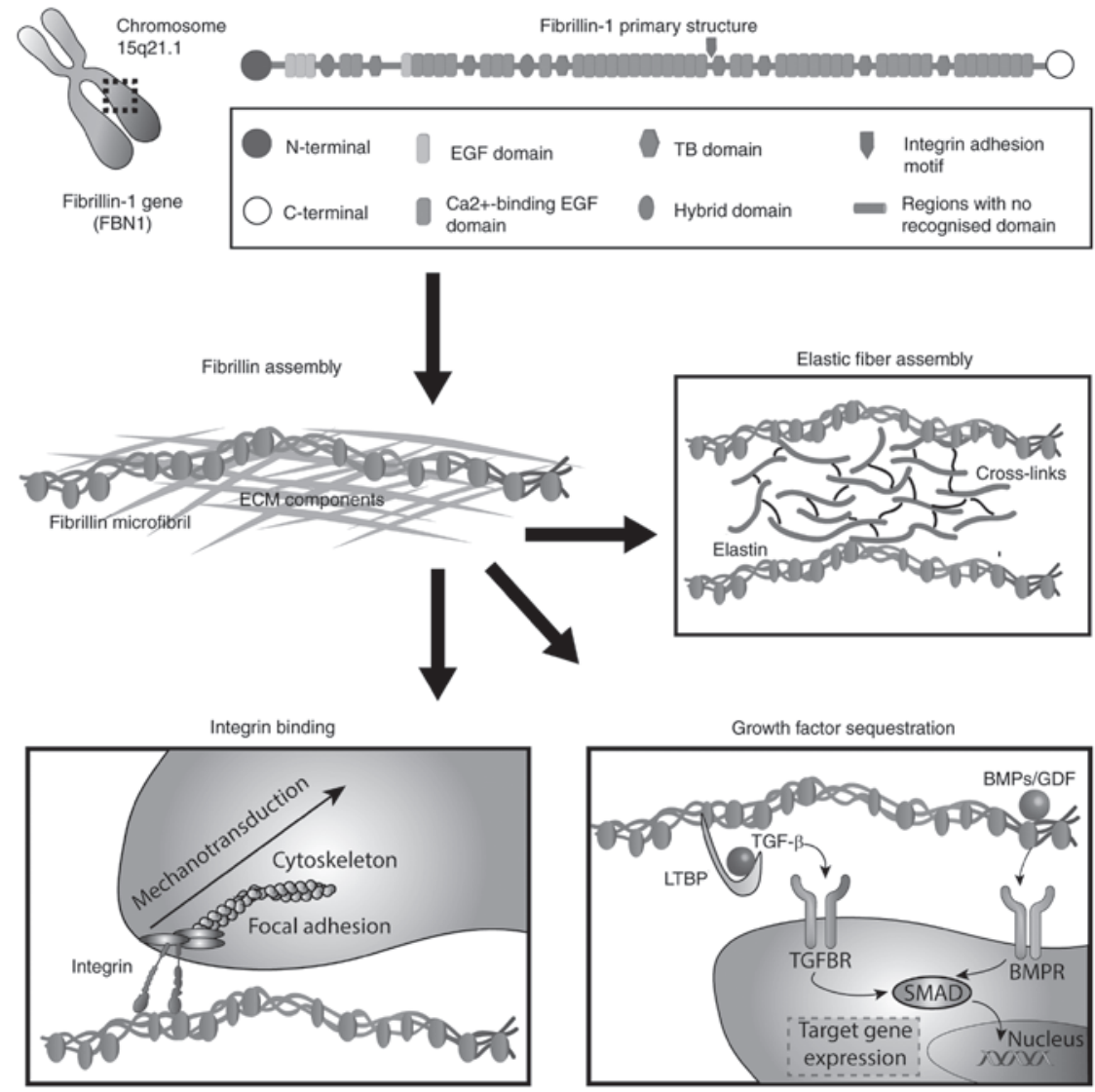

Figure 1. Schematic figure representing the chromosomal location, domain organization and primary functions of human fibrillin. EGF domain, epidermal growth factor-like domain; TGF, transforming growth factor; TB domain, TGF- $\beta$ binding protein-like domain; ECM, extracellular matrix; LTBP, latent TGF- $\beta$-binding protein; BMPs, bone morphogenetic proteins; GDF, growth and differentiation factors; TGFBR, TGF- $\beta$ receptor; BMPR, BMP receptor.

the N-terminus (78). Two precursor proteins homodimerize and, following cleavage by furin-like endoproteases, form a complex that is termed the small latent complex (SLC) (79), in which LAP is non-covalently bound to the active TGF- $\beta$ dimer. The SLC binds covalently to the penultimate TB domain in LTBPs, which together form a complex termed the large latent complex (LLC). The C-terminal region of LTBP-1 and -4 exhibit non-covalent interactions with the $\mathrm{N}$-terminus of FBN-1 within the core of beaded microfibrils, while the N-terminal regions bind to fibronectin. LTBP-3 localizes to microfibrils using a different mechanism (80). The LLC is biologically inactive and TGF- $\beta$ s are accessible to its receptors following proteolytic degradation or conformational changes $(81,82)$ induced by integrin binding or cell-mediated force transmission $(79,83,84)$ The enzymatic activation followed by TGF- $\beta$ release is reported to be mediated by matrix metalloprotease (MMP)-2 and -9 (85), the serine protease plasmin (85-88), thrombospondin-1 (89) and reactive oxygen species (90). Following cleavage and activation, TGF- $\beta$ binds to its serine and threonine kinase receptors (T $\beta R I$ and $\mathrm{T} \beta \mathrm{RII}$ ) on cell membranes, forming a receptor heterocomplex $(77,91)$ that, through Smad signalling activation $(92,93)$, promotes the expression of target genes $(94,95)$, including collagen type $1 \alpha 1$ chain, collagen type $3 \alpha 1$ chain and TIMP metallopeptidase inhibitor 1, in addition to another 60 ECM-associated genes (96). The direct binding of FBN-1 to different BMPs, including BMP-2, $-4,-5,-7$ and -10 , has been previously reported $(73,75,97)$. In addition, there is increasing evidence that other growth factors are indirectly controlled through targeting to other FBN binding partners within the ECM, such as perlecan (57).

\section{Cellular sensing of FBN signalling}

As reported by Zeyer and Reinhardt (80) in 2015, FBN-containing microfibrils, which contain one RGD binding site within the fourth TB domain (98), represent key signal relay molecules for cell attachment, gene expression, spreading, migration and proliferation. In vitro studies on cells cultured on FBN-1 RGD-containing peptides have established the impact of this interaction on cell adhesion and gene expression (99). Cellular interactions have been reported to be mediated via integrins $\left(\alpha_{5} \beta_{1}, \alpha_{5} \beta_{6}, \alpha_{v} \beta_{3}, \alpha_{v} \beta_{6}\right.$ and $\left.\alpha_{8} \beta_{1}\right)(19,99-103)$ and, potentially, by other cellular sensors, including angiotensin II type 1 receptor (AT1) and proteoglycans, such as syndecans $(35,104-106)$. Mutations in regions close to the RGD binding site in FBN-1 lead to a condition that is termed stiff skin syndrome (SSS), a pathological condition that is characterized by excessive skin fibrosis and microfibril accumulation (107). In vitro and in vivo studies employing mice harbouring a mutation in this region reported disturbed cell contact with microfibrils and altered cell spreading. It is reported that AT1 is activated by mechanical stress in cardiac hypertrophy (108). Mice homozygous for a hypomorphic $F B N-1$ allele $\left(F B N-I^{\mathrm{mgR} / \mathrm{mgR}}\right)$ exhibited dilated cardiomyopathy (109). A heparin sulphate binding region upstream of the RGD motif 

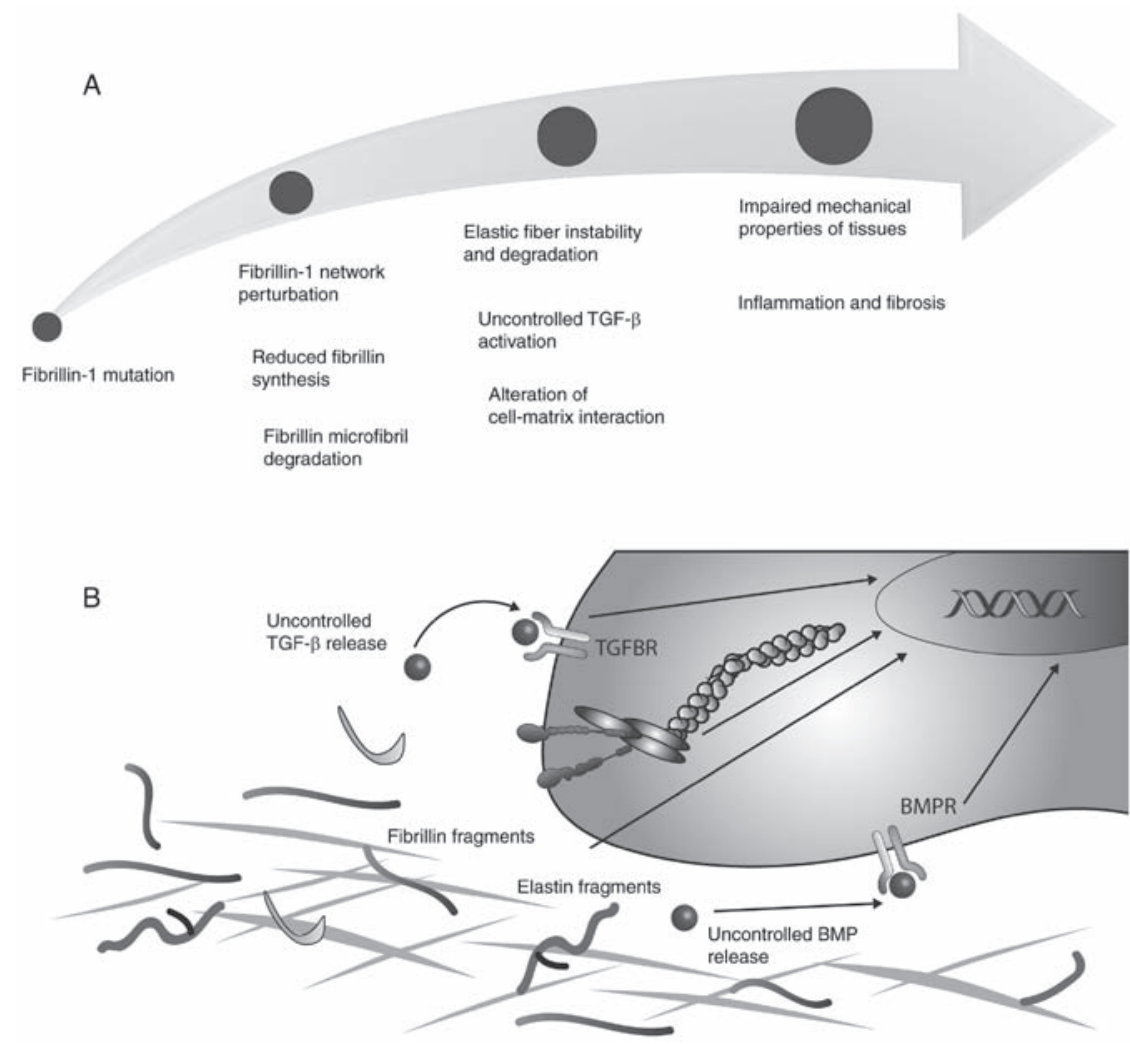

Figure 2. Schematic figure representing the structural and signalling effects of fibrillin mutations and the process of fibrillin network fragmentation. (A) Structural and signalling effects of fibrillin mutations. (B) Process of fibrillin network fragmentation caused by fibrillin mutations. TGF, transforming growth factor; TGFBR, TGF- $\beta$ receptor; BMP, bone morphogenetic protein; BMPR, BMP receptor.

has been reported to be synergistically involved in integrin binding, while another downstream heparan sulphate binding site stimulates the formation of focal adhesion (103) through $\alpha v \beta 3$-integrin (110). It has been demonstrated that, when heparin sulphate signalling is inhibited, the formation of the FBN network is disrupted (104).

\section{FBN diseases in humans}

Due to the number of functions that are controlled to a certain degree by FBN, it is clear that mutations in FBN genes lead to a number of diseases that affect multiple organs, which are collectively termed fibrillinopathies. Mutations in the FBN-1 gene have been demonstrated to cause Marfan syndrome, an autosomal dominant disorder of the connective tissue that is characterized by pleiotropic manifestations in ocular, skeletal and cardiovascular systems. Since the identification of the first mutation in 1991 (111), at present, >1,800 genetic abnormalities have been identified throughout the entire length of FBN-1 (112). Unfortunately, due to phenotypic variability and disease severity, a phenotype-genotype correlation remains to be established $(113,114)$. Mutations in the central region of the FBN-1 gene, comprising exons 24-32, are commonly associated with severe myocardial dysfunctions, neonatal Marfan syndrome and mortality within the first two years of postnatal life (115-117). It is reported that approximately two-thirds of missense mutations involve cysteine residues and lead to ocular complications, while premature terminations are associated with severe skeletal and skin anomalies (115). A growing body of evidence indicates that not all mutations in FBN-1 result in Marfan syndrome; however, those that are not are associated with Marfan-like disorders (118), including MASS phenotype (119), familial thoracic aortic aneurysm $(120,121)$, Shprintzen-Goldberg syndrome (122) and ectopia lentis (123). It has also been established that mutations in FBN-1 may lead to acromelic dysplasias, such as Weill-Marchesani syndrome (WMS), geleophysic dysplasia, acromicric dysplasia and Myhre syndrome $(74,124,125)$. The patients affected by these syndromes generally exhibit short statue, short hands and feet, stiff joints and a hypermuscular build, which is unlike patients with Marfan syndrome, who present with a tall stature, arachnodactyly, hypermobile joints and a thin hypomuscular structure. By contrast to Marfan syndrome, the mutations in FBN-1 that cause acromelic dysplasias, such as WMS, are located in a hot spot within the FBN-1 gene (126) and are in-frame deletions of 24 nucleotides in exon 41 and 42, which encode the fifth TB $(124,126,127)$. An in-frame deletion of exons 9-11, encoding the first TB domain, the proline rich region and the fourth EGF-like domain, have been identified in WMS (74). Notably, while FBN-1 mutations account for the dominant form of WMS, the recessive form is reported to be caused by mutations in ADAMTS10 (128). According to experimental evidence from mouse models expressing RGD sequence mutations and the ability of integrin-modulating therapy to prevent fibrosis and autoimmunity (129), the primary cause of SSS may be the loss of integrin binding sites. A mutation in the TB4 domain has also been reported in patients affected by this syndrome (107). A summary of the structural and signalling effects of mutations in FBN-1 is presented in Fig. 2. 


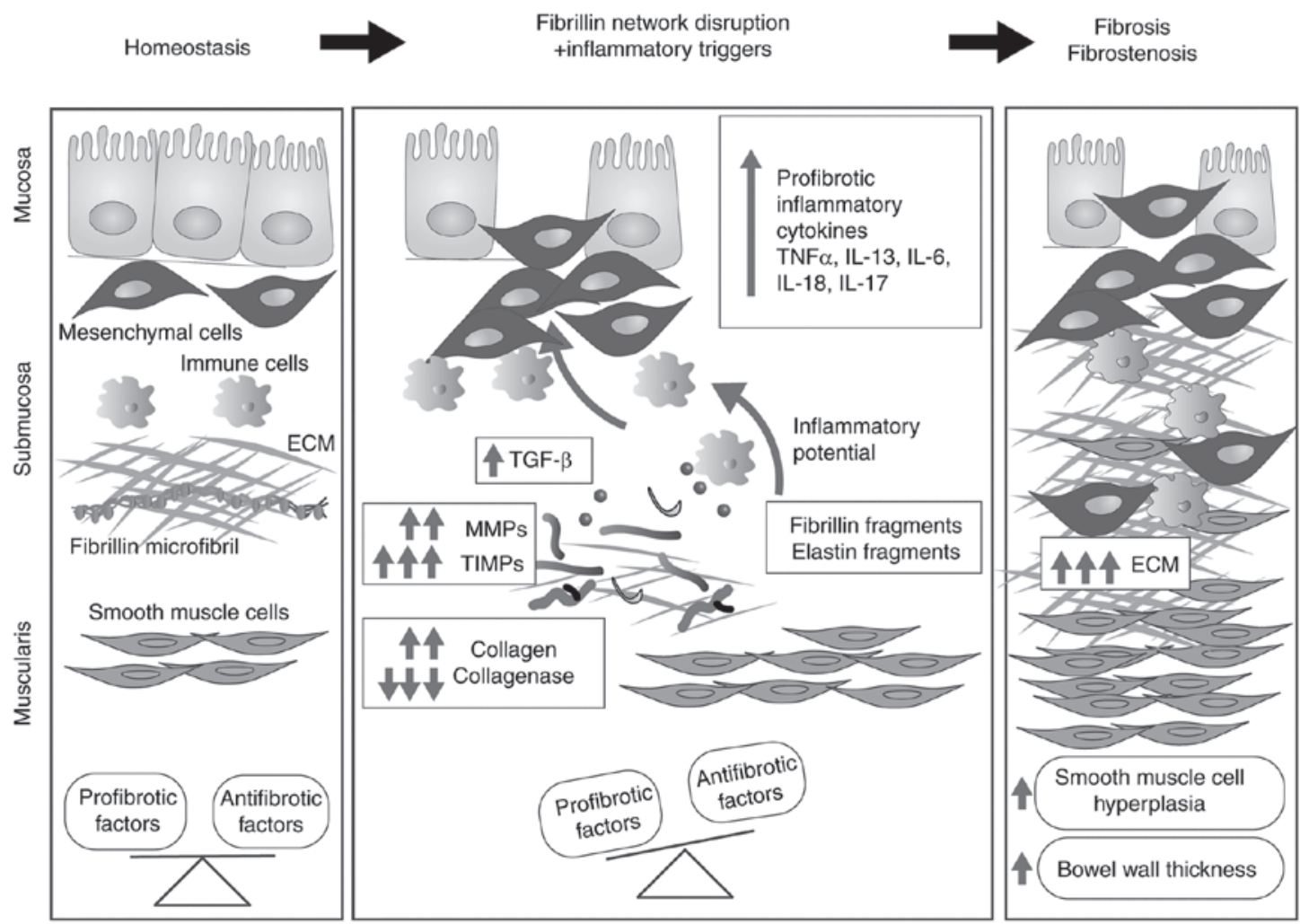

Figure 3. Schematic figure representing the development of gut fibrosis. TNF, tumour necrosis factor; IL, interleukin; ECM, extracellular matrix; TGF, transforming growth factor; MMPs, matrix metalloproteases; TIMPs, TIMP metallopeptidase inhibitors.

\section{In vitro and in vivo studies of $\mathrm{FBN}$ assembly}

Pathophysiological mechanisms accounting for the clinical manifestation of Marfan syndrome and similar disorders are associated with an altered FBN network. Early immunofluorescent studies using anti-FBN antibodies revealed qualitative and quantitative abnormalities of the dermal microfibrils, with a fragmented appearance in tissues extracted from patients with Marfan syndrome. Isolated dermal fibroblasts exhibited a reduced expression of FBN fibres and an abnormal morphology in immunofluorescent analyses $(130,131)$. Differences in microfibril morphology have also been observed in neonatal Marfan syndrome fibroblast cultures (132). In contrast to the fragmented FBN networks observed in Marfan syndrome $(130,133)$, the FBN network in WMS is abnormal for a different reason, as large FBN aggregate accumulations (74) have been reported in the skin of patients with SSS (107). Several in vitro and in vivo studies of FBN-1 disorders have been performed in the last two decades. The dominant negative model is supported by an in vitro study in which the wild-type protein function is disrupted by the mutant FBN, indicating that one FBN-1 mutant allele is sufficient to diminish microfibril assembly (131). Furthermore, data from this model are consistent with published data that reported that low levels of mutant FBN-1 expression in patients with Marfan syndrome is associated with a less severe phenotype (134). On the other hand, haplosufficient models have demonstrated that selected mutations, such as $\mathrm{C} 1039 \mathrm{G}$, lead to a disorganization of the microfibril network, while the C1663R FBN-1 mutation participates in productive microfibril assembly (135). Based on this body of evidence, it is clear that FBN-1 disorders are caused by mechanisms that are dependent on the position and type of mutation. In vivo studies of mutant FBN have indicated that abnormalities within the first hybrid domain do not affect microfibril stability (133), while mutations in cbEGF-like domains perturb microfibril assembly (136). Certain FBN-1 mutations also lead to a gene product that, although it may be assembled into microfibrils with a normal appearance, the mutation destabilizes the structure of FBN-1 and renders it more susceptible to proteolysis, leading to a gradual degradation $(137,138)$. As reported by several studies, the regulation of MMPs is implicated in the pathogenesis of Marfan syndrome and other fibrillinopathies $(139,140)$. In particular, MMP-1, -2 , -3 and -9 appear to exert a pivotal role in FBN fragmentation, as demonstrated by the increased concentration of FBN fragments in the aortic specimens of patients with Marfan syndrome (140-142). Studies concerning connective tissue disorders caused by FBN-1 mutations have also revealed alterations in the targeting and activation of growth factors. In addition, an association between FBN-1 mutations and the altered release of TGF- $\beta$ has been associated with the development of fibrillinopathies (143). In support of this hypothesis, the administration of TGF- $\beta$ antagonists led to anti-apoptotic effects in the lungs of FBN-1-deficient mice (144). Additionally, neutralizing TGF- $\beta$ antibodies successfully prevented the development of aortic aneurysm by normalizing the levels of TGF- $\beta$ in Marfan syndrome mouse models (145). Furthermore, TGF- $\beta$ antagonists have been reported to reduce the levels of circulating TGF- $\beta$ in patients with Marfan syndrome (146). Notably, mutations in LTBPs or TGF- $\beta$ receptors, as observed in Loyes-Dietz syndrome, may lead to the uncontrolled release of TGF- $\beta$. A perturbation of TGF- $\beta$ signalling is also observed 
in other fibrillinopathies, including SSS (107) and acromicric or geleophysic dysplasia (124).

\section{Involvement of FBN-1 in inflammatory disorders}

Scleroderma is a heterogeneous connective tissue disease that is characterized by excessive cutaneous and visceral fibrosis, Raynaud's phenomenon, vascular lesions and gastrointestinal manifestations (147). A widely used mouse model of systemic sclerosis is the tight skin (Tsk) mouse, which exhibits an in-frame tandem duplication of FBN-1 (148). While homozygotes suffer embryonic lethality at day 7-8 of gestation, heterozygotes $(\mathrm{Tsk} /+)$ have a normal life span but manifest myocardial, skeletal, and pulmonary abnormalities. Furthermore, heterozygotes also present with abnormal/altered fibrotic, inflammatory and autoimmune function. Comparable levels of normal and mutant FBN-1 transcripts in Tsk/+ tissues, and the presence of abundant tissue microfibrils, indicates that the mutant FBN-1 is regularly synthesized and assembled (148). Mutant FBN copolymerizes with wild-type FBN-1, which leads to an unstable structure (149) that is more sensitive to proteolysis (150). Briefly, Tsk/+ mice synthesize two types of microfibrils that present with a normal morphology and a well-organized periodicity, or diffuse interbeads, a longer periodicity and a tendency to aggregate (151). The instability of Tsk microfibrils leads to a disorganization and fragmentation of elastic fibres, subsequently leading to reduced ECM integrity $(152,153)$ and increased cellular processing, followed by an autoimmune response and the development of autoantibodies (154). The autoimmune phenotype, however, is not required for the development of dermal thickening observed in Tsk/+ mice, and the Tsk phenotype appears to be independent of the immune system, as this phenotype has also been reported in mice lacking mature $\mathrm{T}$ and B cells $(155,156)$. A potential mechanism involved in the promotion of the fibrotic phenotype may be driven by altered TGF- $\beta$ signalling (157).

\section{Gut-FBN axis}

Inflammatory bowel disease (IBD) comprises a group of gut immunopathological conditions that are a result of genetic, environmental and cellular cues (158). ECM components have important immunoregulatory roles, and the composition and ultrastructure of the ECM are involved in intestinal immune responses, pathological signalling, and chronic inflammation (159). Uncontrolled alterations in ECM composition are reported in IBD and involve collagen I (160), collagen III $(161,162)$, collagen V (163), collagen XVI (164), laminin (165,166), hyaluronan (167) and, recently, FBN-1 (164). FBN and elastic fibre networks have important structural and biomechanical roles within the intestinal tract as they are essential for the peristaltic movement of the gastrointestinal tract. Notably, in up to $90 \%$ of patients with SSS (168), FBN network perturbations are reported to lead to excessive fibrosis, inflammation and vascular dysfunction (169-175). Reinforcing the hypothesis that the FBN network is involved in intestinal homeostasis, a previous study reported the downregulation of FBN in the lamina propria of patients with IBD compared with healthy donors (164). The development of gut fibrosis (176) involves multiple cell types and a large number of soluble factors (Fig. 3). Among soluble factors, TGF- $\beta 1$, which is generally considered to be the key mediator of fibrosis (177), is overexpressed in IBD (178), while under physiological conditions TGF- $\beta 1$ regulates the immune homeostasis by preventing abnormal proinflammatory responses, as demonstrated by the development of severe and lethal systematic inflammation in TGF- $\beta 1$ knockout mice (179) or animals expressing $\mathrm{T}$ cells that do not respond to TGF- $\beta 1$ (180). As observed in other organs, FBN and elastin fragments deriving from unstable networks lead to the upregulated expression of MMPs, including MMP-1, -2, -3, -7, -9, -10, -12 and -13 (181-183), which results in disturbed ECM turnover and subsequent fibrosis $(184,185)$.

\section{Conclusions and perspectives}

FBN-1 is an important ECM component that integrates the biological network of structural and instructive information for the modulation of cell-cell and cell-matrix interactions. Acting as a key relay molecule for the transmission of extracellular information into cellular signalling and function, FBN-1 contributes to the accumulation of latent forms of growth factors, such as TGF- $\beta$ and BMPs, and regulates their bioavailability and activity. Regulating the expression of MMPs, fragmented microfibrils are associated with the development of multiorgan inflammation and fibrosis. At present, the characterization of FBN-1 dysfunction has improved the characterization of the pathological pattern of connective tissue diseases and the identification of novel therapeutic biological approaches for the treatment of inflammation-associated states.

\section{Acknowledgements}

The present study was financially supported by a grant (PRID-2016, to Professor Rosa Di Liddo) from the University of Padova (Padova, Italy).

\section{References}

1. Biery NJ, Eldadah ZA, Moore CS, Stetten G, Spencer F and Dietz HC: Revised genomic organization of FBN1 and significance for regulated gene expression. Genomics 56: 70-77, 1999.

2. Kainulainen K, Pulkkinen L, Savolainen A, Kaitila I and Peltonen L: Location on chromosome 15 of the gene defect causing Marfan syndrome. N Engl J Med 323: 935-939, 1990.

3. Robertson I, Jensen S and Handford P: TB domain proteins: Evolutionary insights into the multifaceted roles of fibrillins and LTBPs. Biochem J 433: 263-276, 2011.

4. Corson GM, Chalberg SC, Dietz HC, Charbonneau NL and Sakai LY: Fibrillin binds calcium and is coded by cDNAs that reveal a multidomain structure and alternatively spliced exons at the 5'end. Genomics 17: 476-484, 1993.

5. Maslen CL, Corson GM, Maddox BK, Glanville RW and Sakai LY: Partial sequence of a candidate gene for the Marfan syndrome. Nature 352: 334-337, 1991.

6. Handford PA, Mayhew M and Brownlee GG: Calcium binding to fibrillin? Nature 353: 395, 1991.

7. Werner JM, Knott V, Handford PA, Campbell ID and Downing AK: Backbone dynamics of a cbEGF domain pair in the presence of calcium. J Mol Biol 296: 1065-1078, 2000.

8. Downing AK, Knott V, Werner JM, Cardy CM, Campbell ID and Handford PA: Solution structure of a pair of calcium-binding epidermal growth factor-like domains: Implications for the Marfan syndrome and other genetic disorders. Cell 85: 597-605, 1996. 
9. Smallridge RS, Whiteman P, Werner JM, Campbell ID Handford PA and Downing AK: Solution structure and dynamics of a calcium binding epidermal growth factor-like domain pair from the neonatal region of human fibrillin-1. J Biol Chem 278: 12199-12206, 2003

10. Reinhardt DP, Mechling DE, Boswell BA, Keene DR, Sakai LY and Bächinger HP: Calcium determines the shape of fibrillin. J Biol Chem 272: 7368-7373, 1997.

11. Reinhardt DP, Ono RN and Sakai LY: Calcium stabilizes fibrillin-1 against proteolytic degradation. J Biol Chem 272: 1231-1236, 1997.

12. Lin G, Tiedemann K, Vollbrandt T, Peters H, Batge B, Brinckmann J and Reinhardt DP: Homo- and heterotypic fibrillin-1 and -2 interactions constitute the basis for the assembly of microfibrils. J Biol Chem 277: 50795-50804, 2002.

13. Marson A, Rock MJ, Cain SA, Freeman LJ, Morgan A, Mellody K, Shuttleworth CA, Baldock C and Kielty CM: Homotypic fibrillin-1 interactions in microfibril assembly. J Biol Chem 280: 5013-5021, 2005.

14. Reinhardt DP, Sasaki T, Dzamba BJ, Keene DR, Chu ML, Göhring W, Timpl R and Sakai LY: Fibrillin-1 and fibulin-2 interact and are colocalized in some tissues. J Biol Chem 271: 19489-19496, 1996.

15. Jensen SA, Reinhardt DP, Gibson MA and Weiss AS: Protein interaction studies of MAGP-1 with tropoelastin and fibrillin-1. J Biol Chem 276: 39661-39666, 2001.

16. Isogai Z, Ono RN, Ushiro S, Keene DR, Chen Y, Mazzieri R, Charbonneau NL, Reinhardt DP, Rifkin DB and Sakai LY: Latent transforming growth factor beta-binding protein 1 interacts with fibrillin and is a microfibril-associated protein. J Biol Chem 278: 2750-2757, 2003.

17. Rock MJ, Cain SA, Freeman LJ, Morgan A, Mellody K, Marson A, Shuttleworth CA, Weiss AS and Kielty CM: Molecular basis of elastic fiber formation. Critical interactions and a tropoelastin-fibrillin-1 cross-link. J Biol Chem 279: 23748-23758, 2004

18. Robertson IB, Horiguchi M, Zilberberg L, Dabovic B, Hadjiolova $\mathrm{K}$ and Rifkin DB: Latent TGF- $\beta$-binding proteins. Matrix Biol 47: 44-53, 2015.

19. Jovanovic J, Takagi J, Choulier L, Abrescia NG, Stuart DI, van der Merwe PA, Mardon HJ and Handford PA: alphaVbeta6 is a novel receptor for human fibrillin-1. Comparative studies of molecular determinants underlying integrin-rgd affinity and specificity. J Biol Chem 282: 6743-6751, 2007.

20. Jensen SA, Iqbal S, Lowe ED, Redfield C and Handford PA Structure and interdomain interactions of a hybrid domain: A disulphide-rich module of the fibrillin/LTBP superfamily of matrix proteins. Structure 17: 759-768, 2009.

21. Lönnqvist L, Reinhardt D, Sakai L and Peltonen L: Evidence for furin-type activity-mediated C-terminal processing of profibrillin-1 and interference in the processing by certain mutations. Hum Mol Genet 7: 2039-2044, 1998.

22. Raghunath M, Putnam EA, Ritty T, Hamstra D, Park ES, Tschödrich-Rotter M, Peters R, Rehemtulla A and Milewicz DM: Carboxy-terminal conversion of profibrillin to fibrillin at a basic site by PACE/furin-like activity required for incorporation in the matrix. J Cell Sci 112: 1093-1100, 1999.

23. Trask TM, Ritty TM, Broekelmann T, Tisdale C and Mecham RP: $\mathrm{N}$-terminal domains of fibrillin 1 and fibrillin 2 direct the formation of homodimers: A possible first step in microfibril assembly. Biochem J 340: 693-701, 1999.

24. Zhang H, Apfelroth SD, Hu W, Davis EC, Sanguineti C, Bonadio J, Mecham RP and Ramirez F: Structure and expression of fibrillin-2, a novel microfibrillar component preferentially located in elastic matrices. J Cell Biol 124: 855-863, 1994

25. Wallis DD, Putnam EA, Cretoiu JS, Carmical SG, Cao SN, Thomas G and Milewicz DM: Profibrillin-1 maturation by human dermal fibroblasts: Proteolytic processing and molecular chaperones. J Cell Biochem 90: 641-652, 2003.

26. Reinhardt DP, Keene DR, Corson GM, Pöschl E, Bächinger HP, Gambee JE and Sakai LY: Fibrillin-1: Organization in microfibrils and structural properties. J Mol Biol 258: 104-116, 1996.

27. Baldock C, Siegler V, Bax DV, Cain SA, Mellody KT Marson A, Haston JL, Berry R, Wang MC, Grossmann JG, et al: Nanostructure of fibrillin-1 reveals compact conformation of EGF arrays and mechanism for extensibility. Proc Natl Acad Sci USA 103: 11922-11927, 2006.

28. Kuo CL, Isogai Z, Keene DR, Hazeki N, Ono RN, Sengle G, Bächinger HP and Sakai LY: Effects of fibrillin-1 degradation on microfibril ultrastructure. J Biol Chem 282: 4007-4020, 2007.
29. Qian RQ and Glanville RW: Alignment of fibrillin molecules in elastic microfibrils is defined by transglutaminase-derived cross-links. Biochemistry 36: 15841-15847, 1997.

30. Keene DR, Maddox BK, Kuo HJ, Sakai LY and Glanville RW: Extraction of extendable beaded structures and their identification as fibrillin-containing extracellular matrix microfibrils. J Histochem Cytochem 39: 441-449, 1991

31. Kielty CM and Shuttleworth CA: Fibrillin-containing microfibrils: Structure and function in health and disease. Int J Biochem Cell Biol 27: 747-760, 1995.

32. Kewley MA, Williams G and Steven FS: Studies of elastic tissue formation in the developing bovine ligamentum nuchae. J Pathol 124: 95-101, 1978.

33. Carta L, Pereira L, Arteaga-Solis E, Lee-Arteaga SY, Lenart B, Starcher B, Merkel CA, Sukoyan M, Kerkis A, Hazeki N, et al: Fibrillins 1 and 2 perform partially overlapping functions during aortic development. J Biol Chem 281: 8016-8023, 2006.

34. Yuan X, Werner JM, Lack J, Knott V, Handford PA, Campbell ID and Downing AK: Effects of the N2144S mutation on backbone dynamics of a TB-cbEGF domain pair from human fibrillin-1. J Mol Biol 316: 113-125, 2002.

35. Yadin DA, Robertson IB, McNaught-Davis J, Evans $\mathrm{P}$, Stoddart D, Handford PA, Jensen SA and Redfield C: Structure of the fibrillin-1 N-terminal domains suggests that heparan sulfate regulates the early stages of microfibril assembly. Structure 21: 1743-1756, 2013

36. Sabatier L, Chen D, Fagotto-Kaufmann C, Hubmacher D, McKee MD, Annis DS, Mosher DF and Reinhardt DP: Fibrillin assembly requires fibronectin. Mol Biol Cell 20: 846-858, 2008.

37. Kinsey R, Williamson MR, Chaudhry S, Mellody KT, McGovern A, Takahashi S, Shuttleworth CA and Kielty CM: Fibrillin-1 microfibril deposition is dependent on fibronectin assembly. J Cell Sci 121: 2696-2704, 2008.

38. Sabatier L, Djokic J, Fagotto-Kaufmann C, Chen M, Annis DS, Mosher DF and Reinhardt DP: Complex contributions of fibronectin to initiation and maturation of microfibrils. Biochem J 456: 283-295, 2013

39. Baldwin AK, Cain SA, Lennon R, Godwin A, Merry CL and Kielty CM: Epithelial-mesenchymal status influences how cells deposit fibrillin microfibrils. J Cell Sci 127: 158-171, 2014.

40. Gibson MA, Kumaratilake JS and Cleary EG: The protein components of the 12-nanometer microfibrils of elastic and nonelastic tissues. J Biol Chem 264: 4590-4598, 1989.

41. Trask BC, Trask TM, Broekelmann T and Mecham RP: The microfibrillar proteins MAGP-1 and fibrillin-1 form a ternary complex with the chondroitin sulfate proteoglycan decorin. Mo Biol Cell 11: 1499-1507, 2000.

42. Mecham RP and Gibson MA: The microfibril-associated glycoproteins (MAGPs) and the microfibrillar niche. Matrix Biol 47: $13-33,2015$

43. Kostka G, Giltay R, Bloch W, Addicks K, Timpl R, Fässler R and Chu ML: Perinatal lethality and endothelial cell abnormalities in several vessel compartments of fibulin-1-deficient mice. Mol Cell Biol 21: 7025-7034, 2001

44. Freeman LJ, Lomas A, Hodson N, Sherratt MJ, Mellody KT, Weiss AS, Shuttleworth A and Kielty CM: Fibulin-5 interacts with fibrillin-1 molecules and microfibrils. Biochem J 388: 1-5, 2005.

45. Yanagisawa H, Davis EC, Starcher BC, Ouchi T, Yanagisawa M, Richardson JA and Olson EN: Fibulin-5 is an elastin-binding protein essential for elastic fibre development in vivo. Nature 415: 168-171, 2002.

46. Hirai M, Ohbayashi T, Horiguchi M, Okawa K, Hagiwara A, Chien KR, Kita T and Nakamura T: Fibulin-5/DANCE has an elastogenic organizer activity that is abrogated by proteolytic cleavage in vivo. J Cell Biol 176: 1061-1071, 2007.

47. Gabriel LA, Wang LW, Bader H, Ho JC, Majors AK, Hollyfield JG, Traboulsi EI and Apte SS: ADAMTSL4, a secreted glycoprotein widely distributed in the eye, binds fibrillin-1 microfibrils and accelerates microfibril biogenesis. Invest Ophthalmol Vis Sci 53 461-469, 2012.

48. Tsutsui K, Manabe R, Yamada T, Nakano I, Oguri Y, Keene DR, Sengle G, Sakai LY and Sekiguchi K: ADAMTSL-6 is a novel extracellular matrix protein that binds to fibrillin-1 and promotes fibrillin-1 fibril formation. J Biol Chem 285: 4870-4882, 2010.

49. Kutz WE, Wang LW, Bader HL, Majors AK, Iwata K, Traboulsi EI, Sakai LY, Keene DR and Apte SS: ADAMTS10 protein interacts with fibrillin-1 and promotes its deposition in extracellular matrix of cultured fibroblasts. J Biol Chem 286 17156-17167, 2011 
50. Hubmacher D and Apte SS: ADAMTS proteins as modulators of microfibril formation and function. Matrix Biol 47: 34-43, 2015.

51. Iozzo RV: Basement membrane proteoglycans: From cellar to ceiling. Nat Rev Mol Cell Biol 6: 646-656, 2005.

52. Murdoch AD, Liu B, Schwarting R, Tuan RS and Iozzo RV: Widespread expression of perlecan proteoglycan in basement membranes and extracellular matrices of human tissues as detected by a novel monoclonal antibody against domain III and by in situ hybridization. J Histochem Cytochem 42: 239-249, 1994.

53. Reinboth B, Hanssen E, Cleary EG and Gibson MA: Molecular interactions of biglycan and decorin with elastic fiber components: Biglycan forms a ternary complex with tropoelastin and microfibril-associated glycoprotein 1. J Biol Chem 277: 3950-3957, 2002.

54. Raghunath M, Superti-Furga A, Godfrey M and Steinmann B: Decreased extracellular deposition of fibrillin and decorin in neonatal Marfan syndrome fibroblasts. Hum Genet 90: 511-515, 1993.

55. Superti-Furga A, Raghunath $M$ and Willems PJ: Deficiencies of fibrillin and decorin in fibroblast cultures of a patient with neonatal Marfan syndrome. J Med Genet 29: 875-878, 1992.

56. Hayes AJ, Lord MS, Smith SM, Smith MM, Whitelock JM, Weiss AS and Melrose J: Colocalization in vivo and association in vitro of perlecan and elastin. Histochem Cell Biol 136: 437-454, 2011

57. Tiedemann K, Sasaki T, Gustafsson E, Göhring W, Bätge B, Notbohm H, Timpl R, Wedel T, Schlötzer-Schrehardt U and Reinhardt DP: Microfibrils at basement membrane zones interact with perlecan via fibrillin-1.J Biol Chem 280: 11404-11412, 2005

58. Whitelock JM, Melrose J and Iozzo RV: Diverse cell signaling events modulated by perlecan. Biochemistry 47: 11174-11183, 2008.

59. Kerever A, Mercier F, Nonaka R, de Vega S, Oda Y, Zalc B, Okada Y, Hattori N, Yamada Y and Arikawa-Hirasawa E: Perlecan is required for FGF-2 signaling in the neural stem cell niche. Stem Cell Res 12: 492-505, 2014.

60. Thisse B and Thisse C: Functions and regulations of fibroblast growth factor signaling during embryonic development. Dev Biol 287: 390-402, 2005

61. Murasawa Y, Watanabe K, Yoneda M, Zako M, Kimata K, Sakai LY and Isogai Z: Homotypic versican G1 domain interactions enhance hyaluronan incorporation into fibrillin microfibrils. J Biol Chem 288: 29170-29181, 2013.

62. Wight TN and Merrilees MJ: Proteoglycans in atherosclerosis and restenosis: Key roles for versican. Circ Res 94: 1158-1167, 2004

63. Wu YJ, La Pierre DP, Wu J, Yee AJ and Yang BB: The interaction of versican with its binding partners. Cell Res 15: 483-494, 2005

64. Zheng PS, Vais D, Lapierre D, Liang YY, Lee V, Yang BL and Yang BB: PG-M/versican binds to P-selectin glycoprotein ligand-1 and mediates leukocyte aggregation. J Cell Sci 117: 5887-5895, 2004.

65. Grässel S, Unsöld C, Schäcke H, Bruckner-Tuderman L and Bruckner P: Collagen XVI is expressed by human dermal fibroblasts and keratinocytes and is associated with the microfibrillar apparatus in the upper papillary dermis. Matrix Biol 18: 309-317, 1999.

66. Hubert T, Grimal S, Ratzinger S, Mechaly I, Grassel S and Fichard-Carroll A: Collagen XVI is a neural component of the developing and regenerating dorsal root ganglia extracellular matrix. Matrix Biol 26: 206-210, 2007.

67. Ono RN, Sengle G, Charbonneau NL, Carlberg V, Bächinger HP, Sasaki T, Lee-Arteaga S, Zilberberg L, Rifkin DB, Ramirez F, et al: Latent transforming growth factor beta-binding proteins and fibulins compete for fibrillin- 1 and exhibit exquisite specificities in binding sites. J Biol Chem 284: 16872-16881, 2009.

68. Dallas SL, Sivakumar P, Jones CJ, Chen Q, Peters DM, Mosher DF, Humphries MJ and Kielty CM: Fibronectin regulates latent transforming growth factor-beta (TGF beta) by controlling matrix assembly of latent TGF-beta binding protein-1. J Biol Chem 280: 18871-18880, 2005.

69. Fontana L, Chen Y, Prijatelj P, Sakai T, Fässler R, Sakai LY and Rifkin DB: Fibronectin is required for integrin alphavbeta6-mediated activation of latent TGF-beta complexes containing LTBP-1. FASEB J 19: 1798-1808, 2005

70. Kantola AK, Keski-Oja J and Koli K: Fibronectin and heparin binding domains of latent TGF-beta binding protein (LTBP)-4 mediate matrix targeting and cell adhesion. Exp Cell Res 314: 2488-2500, 2008.
71. Saharinen J, Hyytiäinen M, Taipale J and Keski-Oja J Latent transforming growth factor-beta binding proteins (LTBPs)-structural extracellular matrix proteins for targeting TGF-beta action. Cytokine Growth Factor Rev 10: 99-117, 1999.

72. Gregory KE, Ono RN, Charbonneau NL, Kuo CL, Keene DR, Bachinger HP and Sakai LY: The prodomain of BMP-7 targets the BMP-7 complex to the extracellular matrix. J Biol Chem 280: 27970-27980, 2005.

73. Sengle G, Charbonneau NL, Ono RN, Sasaki T, Alvarez J, Keene DR, Bächinger HP and Sakai LY: Targeting of bone morphogenetic protein growth factor complexes to fibrillin. J Biol Chem 283: 13874-13888, 2008.

74. Sengle G, Tsutsui K, Keene DR, Tufa SF, Carlson EJ, Charbonneau NL, Ono RN, Sasaki T, Wirtz MK, Samples JR, et al: Microenvironmental regulation by fibrillin-1. PLoS Genet 8: e1002425, 2012

75. Wohl AP, Troilo H, Collins RF, Baldock C and Sengle G: Extracellular regulation of bone morphogenetic protein activity by the microfibril component fibrillin-1. J Biol Chem 291 : 12732-12746, 2016.

76. Charbonneau NL, Ono RN, Corson GM, Keene DR and Sakai LY: Fine tuning of growth factor signals depends on fibrillin microfibril networks. Birth Defects Res Part C Embryo Today 72: 37-50, 2004.

77. Massagué J and Chen YG: Controlling TGF-beta signaling. Genes Dev 14: 627-644, 2000.

78. Lawrence DA, Pircher R, Krycève-Martinerie C and Jullien P: Normal embryo fibroblasts release transforming growth factors in a latent form. J Cell Physiol 121: 184-188, 1984.

79. Shi M, Zhu J, Wang R, Chen X, Mi L, Walz T and Springer TA Latent TGF- $\beta$ structure and activation. Nature 474: 343-349, 2011.

80. Zeyer KA and Reinhardt DP: Fibrillin-containing microfibrils are key signal relay stations for cell function. J Cell Commun Signal 9: 309-325, 2015.

81. Dubois CM, Laprise MH, Blanchette F, Gentry LE and Leduc R Processing of transforming growth factor beta 1 precursor by human furin convertase. J Biol Chem 270: 10618-10624, 1995.

82. Nunes I, Munger J, Harpel JG, Nagano Y, Shapiro R, Gleizes PE and Rifkin DB: Structure and activation of the large latent transforming growth factor-Beta complex. J Am Optom Assoc 69: 643-648, 1998

83. Annes JP, Munger JS and Rifkin DB: Making sense of latent TGFbeta activation. J Cell Sci 116: 217-224, 2003.

84. Hinz B: It has to be the $\alpha \mathrm{v}$ : Myofibroblast integrins activate latent TGF- $\beta 1$. Nat Med 19: 1567-1568, 2013.

85. Sato $\mathrm{Y}$ and Rifkin DB: Inhibition of endothelial cell movement by pericytes and smooth muscle cells: Activation of a latent transforming growth factor-beta 1-like molecule by plasmin during co-culture. J Cell Biol 109: 309-315, 1989.

86. Yu Q and Stamenkovic I: Cell surface-localized matrix metalloproteinase-9 proteolytically activates TGF-beta and promotes tumor invasion and angiogenesis. Genes Dev 14: $163-176,2000$

87. Jenkins G: The role of proteases in transforming growth factor-beta activation. Int J Biochem Cell Biol 40: 1068-1078, 2008.

88. Lyons RM, Gentry LE, Purchio AF and Moses HL: Mechanism of activation of latent recombinant transforming growth factor beta 1 by plasmin. J Cell Biol 110: 1361-1367, 1990.

89. Schultz-Cherry S and Murphy-Ullrich JE: Thrombospondin causes activation of latent transforming growth factor-beta secreted by endothelial cells by a novel mechanism. J Cell Biol 122: 923-932, 1993

90. Barcellos-Hoff MH, Derynck R, Tsang ML and Weatherbee JA: Transforming growth factor-beta activation in irradiated murine mammary gland. J Clin Invest 93: 892-899, 1994.

91. Schmierer B and Hill CS: TGFbeta-SMAD signal transduction: Molecular specificity and functional flexibility. Nat Rev Mol Cell Biol 8: 970-982, 2007

92. Chen X and Xu L: Mechanism and regulation of nucleocytoplasmic trafficking of smad. Cell Biosci 1: 40, 2011.

93. Tang LY and Zhang YE: Non-degradative ubiquitination in Smad-dependent TGF- $\beta$ signaling. Cell Biosci 1: 43, 2011.

94. Feng XH and Derynck R: Specificity and versatility in tgf-beta signaling through Smads. Annu Rev Cell Dev Biol 21: 659-693, 2005.

95. Massagué J, Seoane J and Wotton D: Smad transcription factors. Genes Dev 19: 2783-2810, 2005 
96. Verrecchia F, Chu ML and Mauviel A: Identification of novel TGF-beta/Smad gene targets in dermal fibroblasts using a combined cDNA microarray/promoter transactivation approach J Biol Chem 276: 17058-17062, 2001

97. Sengle G, Ono RN, Sasaki T and Sakai LY: Prodomains of transforming growth factor beta (TGFbeta) superfamily members specify different functions: Biglycan forms a ternary complex with tropoelastin and microfibril-associated glycoprotein 1. J Biol Chem 286: 5087-5099, 2011.

98. Pereira L, D'Alessio M, Ramirez F, Lynch JR, Sykes B, Pangilinan $\mathrm{T}$ and Bonadio J: Genomic organization of the sequence coding for fibrillin, the defective gene product in Marfan syndrome. Hum Mol Genet 2: 1762, 1993.

99. Bax DV, Bernard SE, Lomas A, Morgan A, Humphries J, Shuttleworth CA, Humphries MJ and Kielty CM: Cell adhesion to fibrillin-1 molecules and microfibrils is mediated by alpha 5 beta 1 and alpha v beta 3 integrins. J Biol Chem 278 34605-34616, 2003.

100. Marek I, Volkert G, Hilgers KF, Bieritz B, Rascher W, Reinhardt DP and Hartner A: Fibrillin-1 and alpha8 integrin are co-expressed in the glomerulus and interact to convey adhesion of mesangial cells. Cell Adh Migr 8: 389-395, 2014.

101. Lee SS, Knott V, Jovanović J, Harlos K, Grimes JM, Choulier L, Mardon HJ, Stuart DI and Handford PA: Structure of the integrin binding fragment from fibrillin-1 gives new insights into microfibril organization. Structure 12: 717-729, 2004

102. Bouzeghrane F, Reinhardt DP, Reudelhuber TL and Thibault G: Enhanced expression of fibrillin-1, a constituent of the myocardial extracellular matrix in fibrosis. Am J Physiol Heart Circ Physiol 289: H982-H991, 2005.

103. Bax DV, Mahalingam Y, Cain S, Mellody K, Freeman L, Younger K, Shuttleworth CA, Humphries MJ, Couchman JR and Kielty CM: Cell adhesion to fibrillin-1: Identification of an Arg-Gly-Asp-dependent synergy region and a heparin-binding site that regulates focal adhesion formation. J Cell Sci 120 1383-1392, 2007.

104. Tiedemann K, Bätge B, Müller PK and Reinhardt DP Interactions of fibrillin-1 with heparin/heparan sulfate, implications for microfibrillar assembly. J Biol Chem 276: 36035-36042, 2001.

105. Cain SA, Baldwin AK, Mahalingam Y, Raynal B, Jowitt TA, Shuttleworth CA, Couchman JR and Kielty CM: Heparan sulfate regulates fibrillin-1 N- and C-terminal interactions. J Biol Chem 283: 27017-27027, 2008

106. Alexopoulou AN, Multhaupt HA and Couchman JR: Syndecans in wound healing, inflammation and vascular biology. Int J Biochem Cell Biol 39: 505-528, 2007.

107. Loeys BL, Gerber EE, Riegert-Johnson D, Iqbal S, Whiteman P, McConnell V, Chillakuri CR, Macaya D, Coucke PJ, De Paepe A, et al: Mutations in fibrillin-1 cause congenital scleroderma: Stiff skin syndrome. Sci Transl Med 2: 23ra20, 2010

108. Zou Y, Akazawa H, Qin Y, Sano M, Takano H, Minamino T, Makita N, Iwanaga K, Zhu W, Kudoh S, et al: Mechanical stress activates angiotensin II type 1 receptor without the involvement of angiotensin II. Nat Cell Biol 6: 499-506, 2004

109. Cook JR, Carta L, Bénard L, Chemaly ER, Chiu E, Rao SK, Hampton TG, Yurchenco P; GenTAC Registry Consortium, Costa KD, et al: Abnormal muscle mechanosignaling triggers cardiomyopathy in mice with Marfan syndrome. J Clin Invest 124: 1329-1339, 2014

110. Weber E, Rossi A, Solito R, Sacchi G, Agliano' M and Gerli R Focal adhesion molecules expression and fibrillin deposition by lymphatic and blood vessel endothelial cells in culture. Microvasc Res 64: 47-55, 2002

111. Dietz HC, Cutting CR, Pyeritz RE, Maslen CL, Sakai LY, Corson GM, Puffenberger EG, Hamosh A, Nanthakumar EJ, Curristin SM, et al: Marfan syndrome caused by a recurrent de novo missense mutation in the fibrillin gene. Nature 352: 337-339, 1991.

112. Collod-Béroud G, Le Bourdelles S, Ades L, Ala-Kokko L, Booms P, Boxer M, Child A, Comeglio P, De Paepe A, Hyland JC, et al: Update of the UMD-FBN1 mutation database and creation of an FBN1 polymorphism database. Hum Mutat 22: 199-208, 2003

113. Ramirez F and Dietz HC: Marfan syndrome: From molecular pathogenesis to clinical treatment. Curr Opin Genet Dev 17: 252-258, 2007.
114. Sakai LY, Keene DR, Renard M and De Backer J: FBN1: The disease-causing gene for Marfan syndrome and other genetic disorders. Gene 591: 279-291, 2016.

115. Faivre L, Collod-Beroud G, Loeys BL, Child A, Binquet C, Gautier E, Callewaert B, Arbustini E, Mayer K, Arslan-Kirchner M, et al: Effect of mutation type and location on clinical outcome in 1,013 probands with marfan syndrome or related phenotypes and fbn 1 mutations: An international study. Am J Hum Genet 81: 454-466, 2007.

116. Booms P, Cisler J, Mathews KR, Godfrey M, Tiecke F, Kaufmann UC, Vetter U, Hagemeier $\mathrm{C}$ and Robinson PN: Novel exon skipping mutation in the fibrillin-1 gene: Two 'hot spots' for the neonatal Marfan syndrome. Clin Genet 55: 110-117, 1999.

117. Morse RP, Rockenmacher S, Pyeritz RE, Sanders SP, Bieber FR, Lin A, MacLeod P, Hall B and Graham JM Jr: Diagnosis and management of infantile marfan syndrome. Pediatrics 86: 888-895, 1990.

118. Loeys BL, Dietz HC, Braverman AC, Callewaert BL, De Backer J, Devereux RB, Hilhorst-Hofstee Y, Jondeau G, Faivre L, Milewicz DM, et al: The revised Ghent nosology for the Marfan syndrome. J Med Genet 47: 476-485, 2010.

119. Dietz HC and Pyeritz RE: Mutations in the human gene for fibrillin-1 (FBN1) in the Marfan syndrome and related disorders. Hum Mol Genet 4 Spec No: 1799-1809, 1995.

120. Francke U, Berg MA, Tynan K, Brenn T, Liu W, Aoyama T, Gasner C, Miller DC and Furthmayr H: A Gly1127Ser mutation in an EGF-like domain of the fibrillin-1 gene is a risk factor for ascending aortic aneurysm and dissection. Am J Hum Genet 56: 1287-1296, 1995.

121. Yamawaki T, Nagaoka K, Morishige K, Sadamatsu K, Tashiro H, Yasunaga $\mathrm{H}$, Morisaki $\mathrm{H}$ and Morisaki T: Familial thoracic aortic aneurysm and dissection associated with Marfan-related gene mutations: Case report of a family with two gene mutations. Intern Med 48: 555-558, 2009.

122. Sood S, Eldadah ZA, Krause WL, McIntosh I and Dietz HC: Mutation in fibrillin-1 and the Marfanoid-craniosynostosis (Shprintzen-Goldberg) syndrome. Nat Genet 12: 209-211, 1996.

123. Kainulainen K, Karttunen L, Puhakka L, Sakai L and Peltonen L: Mutations in the fibrillin gene responsible for dominant ectopia lentis and neonatal Marfan syndrome. Nat Genet 6: 64-69, 1994

124. Le Goff C, Mahaut C, Wang LW, Allali S, Abhyankar A, Jensen S, Zylberberg L, Collod-Beroud G, Bonnet D, Alanay Y, et al: Mutations in the TGF $\beta$ Binding-protein-like domain 5 of FBN1 are responsible for acromicric and geleophysic dysplasias. Am J Hum Genet 89: 7-14, 2011.

125. Faivre L, Dollfus H, Lyonnet S, Alembik Y, Mégarbané A, Samples J, Gorlin RJ, Alswaid A, Feingold J, Le Merrer M, et al: Clinical homogeneity and genetic heterogeneity in Weill-Marchesani syndrome. Am J Med Genet A 123A 204-207, 2003

126. Cecchi A, Ogawa N, Martinez HR, Carlson A, Fan Y, Penny DJ, Guo DC, Eisenberg S, Safi H, Estrera A, et al: Missense mutations in FBN1 exons 41 and 42 cause Weill-Marchesani syndrome with thoracic aortic disease and Marfan syndrome. Am J Med Genet Part A 161A: 2305-2310, 2013

127. Faivre L, Gorlin RJ, Wirtz MK, Godfrey M, Dagoneau N, Samples JR, Le Merrer M, Collod-Beroud G, Boileau C, Munnich A and Cormier-Daire V: In frame fibrillin-1 gene deletion in autosomal dominant Weill-Marchesani syndrome. J Med Genet 40: 34-36, 2003

128. Dagoneau N, Benoist-Lasselin C, Huber C, Faivre L, Mégarbané A, Alswaid A, Dollfus H, Alembik Y, Munnich A, Legeai-Mallet L and Cormier-Daire V: ADAMTS10 mutations in autosomal recessive Weill-Marchesani syndrome. Am J Hum Genet 75: 801-806, 2004

129. Gerber EE, Gallo EM, Fontana SC, Davis EC, Wigley FM, Huso DL and Dietz HC: Integrin-modulating therapy prevents fibrosis and autoimmunity in mouse models of scleroderma. Nature 503: 126-130, 2013

130. Hollister DW, Godfrey M, Sakai LY and Pyeritz RE: Immunohistologic abnormalities of the Microfibrillar-fiber system in the marfan syndrome. N Engl J Med 323: 152-159, 1990.

131. Eldadah ZA, Brenn T, Furthmayr H and Dietz HC: Expression of a mutant human fibrillin allele upon a normal human or murine genetic background recapitulates a Marfan cellular phenotype. J Clin Invest 95: 874-880, 1995. 
132. Godfrey M, Raghunath M, Cisler J, Bevins CL, DePaepe A, Di Rocco M, Gregoritch J, Imaizumi K, Kaplan P, Kuroki Y, et al: Abnormal morphology of fibrillin microfibrils in fibroblast cultures from patients with neonatal Marfan syndrome. Am J Pathol 146: 1414-1421, 1995.

133. Charbonneau NL, Carlson EJ, Tufa S, Sengle G, Manalo EC, Carlberg VM, Ramirez F, Keene DR and Sakai LY: In vivo studies of mutant Fibrillin-1 microfibrils. J Biol Chem 285: 24943-24955, 2010

134. Aoyama T, Tynan K, Dietz HC, Francke U and Furthmayr H: Missense mutations impair intracellular processing of fibrillin and microfibril assembly in Marfan syndrome. Hum Mol Genet 2: 2135-2140, 1993

135. Judge DP, Biery NJ, Keene DR, Geubtner J, Myers L, Huso DL, Sakai LY and Dietz HC: Evidence for a critical contribution of haploinsufficiency in the complex pathogenesis of Marfan syndrome. J Clin Invest 114: 172-181, 2004.

136. Arbustini E, Grasso M, Ansaldi S, Malattia C, Pilotto A, Porcu E, DisabellaE,Marziliano N,Pisani A,LanzariniL, etal: Identification of sixty-two novel and twelve known FBN1 mutations in eighty-one unrelated probands with Marfan syndrome and other fibrillinopathies. Hum Mutat 26: 494, 2005.

137. Reinhardt DP, Ono RN, Notbohm H, Müller PK, Bächinger HP and Sakai LY: Mutations in calcium-binding epidermal growth factor modules render fibrillin-1 susceptible to proteolysis. A potential disease-causing mechanism in Marfan syndrome. J Biol Chem 275: 12339-12345, 2000.

138. Booms P, Tiecke F, Rosenberg T, Hagemeier C and Robinson PN: Differential effect of FBN1 mutations on in vitro proteolysis of recombinant fibrillin-1 fragments. Hum Genet 107: 216-224, 2000.

139. Hindson VJ, Ashworth JL, Rock MJ, Cunliffe S, Shuttleworth CA and Kielty CM: Fibrillin degradation by matrix metalloproteinases: Identification of amino- and carboxy-terminal cleavage sites. FEBS Lett 452: 195-198, 1999.

140. Ikonomidis JS, Jones JA, Barbour JR, Stroud RE, Clark LL, Kaplan BS, Zeeshan A, Bavaria JE, Gorman JH III, Spinale FG and Gorman RC: Expression of matrix metalloproteinases and endogenous inhibitors within ascending aortic aneurysms of patients with Marfan syndrome. Circulation 114 (Suppl 1): I365-I370, 2006.

141. Segura AM, Luna RE, Horiba K, Stetler-Stevenson WG, McAllister HA Jr, Willerson JT and Ferrans VJ: Immunohistochemistry of matrix metalloproteinases and their inhibitors in thoracic aortic aneurysms and aortic valves of patients with Marfan's syndrome. Circulation 98 (Suppl 19): II331-II338, 1998

142. Fleischer KJ, Nousari HC, Anhalt GJ, Stone CD and Laschinger JC: Immunohistochemical abnormalities of fibrillin in cardiovascular tissues in Marfan's syndrome. Ann Thorac Surg 63: 1012-1017, 1997.

143. Granata A, Serrano F, Bernard WG, McNamara M, Low L, Sastry P and Sinha S: An iPSC-derived vascular model of Marfan syndrome identifies key mediators of smooth muscle cell death. Nat Genet 49: 97-109, 2017.

144. Neptune ER, Frischmeyer PA, Arking DE, Myers L, Bunton TE, Gayraud B, Ramirez F, Sakai LY and Dietz HC: Dysregulation of TGF-beta activation contributes to pathogenesis in Marfan syndrome. Nat Genet 33: 407-411, 2003.

145. Ng CM, Cheng A, Myers LA, Martinez-Murillo F, Jie C, Bedja D, Gabrielson KL, Hausladen JM, Mecham RP, Judge DP and Dietz HC: TGF-beta-dependent pathogenesis of mitral valve prolapse in a mouse model of Marfan syndrome. J Clin Invest 114: 1586-1592, 2004.

146. Franken R, den Hartog AW, de Waard V, Engele L, Radonic T, Lutter R, Timmermans J, Scholte AJ, van den Berg MP, Zwinderman $\mathrm{AH}$, et al: Circulating transforming growth factor- $\beta$ as a prognostic biomarker in Marfan syndrome. Int J Cardiol 168: 2441-2446, 2013

147. Pattanaik D, Brown M and Postlethwaite AE: Vascular involvement in systemic sclerosis (scleroderma). J Inflamm Res 4: 105-125, 2011.

148. Siracusa LD, McGrath R, Ma Q, Moskow JJ, Manne J, Christner PJ, Buchberg AM and Jimenez SA: A tandem duplication within the fibrillin 1 gene is associated with the mouse tight skin mutation. Genome Res 6: 300-313, 1996.

149. Lemaire R, Bayle J and Lafyatis R: Fibrillin in Marfan syndrome and tight skin mice provides new insights into transforming growth factor-beta regulation and systemic sclerosis. Curr Opin Rheumatol 18: 582-587, 2006.
150. Gayraud B, Keene DR, Sakai LY and Ramirez F: New insights into the assembly of extracellular microfibrils from the analysis of the fibrillin 1 mutation in the tight skin mouse. J Cell Biol 150: 667-680, 2000.

151. Kielty CM, Raghunath M, Siracusa LD, Sherratt MJ, Peters R, Shuttleworth CA and Jimenez SA: The tight skin mouse: Demonstration of mutant fibrillin-1 production and assembly into abnormal microfibrils. J Cell Biol 140: 1159-1166, 1998.

152. Saito S, Nishimura H, Brumeanu TD, Casares S, Stan AC, Honjo T and Bona CA: Characterization of mutated protein encoded by partially duplicated fibrillin-1 gene in tight skin (TSK) mice. Mol Immunol 36: 169-176, 1999.

153. Gardi C, Martorana PA, de Santi MM, van Even P and Lungarella G: A biochemical and morphological investigation of the early development of genetic emphysema in tight-skin mice. Exp Mol Pathol 50: 398-410, 1989.

154. Tan FK, Arnett FC, Antohi S, Saito S, Mirarchi A, Spiera H, Sasaki T, Shoichi O, Takeuchi K, Pandey JP, et al: Autoantibodies to the extracellular matrix microfibrillar protein, fibrillin-1, in patients with scleroderma and other connective tissue diseases. J Immunol 163: 1066-1072, 1999.

155. Siracusa LD, McGrath R, Fisher JK and Jimenez SA: The mouse tight skin (Tsk) phenotype is not dependent on the presence of mature T and B lymphocytes. Mamm Genome 9: 907-909, 1998.

156. Dodig TD, Mack KT, Cassarino DF and Clark SH: Development of the tight-skin phenotype in immune-deficient mice. Arthritis Rheum 44: 723-727, 2001.

157. Kissin EY, Lemaire R, Korn JH and Lafyatis R: Transforming growth factor beta induces fibroblast fibrillin-1 matrix formation. Arthritis Rheum 46: 3000-3009, 2002.

158. Podolsky DK: Inflammatory bowel disease. N Engl J Med 347: 417-429, 2002

159. Shimshoni E, Yablecovitch D, Baram L, Dotan I and Sagi I: ECM remodelling in IBD: Innocent bystander or partner in crime? The emerging role of extracellular molecular events in sustaining intestinal inflammation. Gut 64: 367-372, 2015.

160. Stumpf M, Cao W, Klinge U, Klosterhalfen B, Junge K, Krones CJ and Schumpelick V: Reduced expression of collagen type I and increased expression of matrix metalloproteinases 1 in patients with Crohn's disease. J Invest Surg 18: 33-38, 2005.

161. Stumpf M, Cao W, Klinge U, Klosterhalfen B, Kasperk R and Schumpelick V: Increased distribution of collagen type III and reduced expression of matrix metalloproteinase 1 in patients with diverticular disease. Int J Colorectal Dis 16: 271-275, 2001.

162. Stallmach A, Schuppan D, Riese HH, Matthes H and Riecken EO: Increased collagen type III synthesis by fibroblasts isolated from strictures of patients with Crohn's disease. Gastroenterology 102: 1920-1929, 1992.

163. Graham MF, Diegelmann RF, Elson CO, Lindblad WJ, Gotschalk N, Gay S and Gay R: Collagen content and types in the intestinal strictures of Crohn's disease. Gastroenterology 94: $257-265,1988$

164. Ratzinger S, Eble JA, Pasoldt A, Opolka A, Rogler G, Grifka J and Grässel S: Collagen XVI induces formation of focal contacts on intestinal myofibroblasts isolated from the normal and inflamed intestinal tract. Matrix Biol 29: 177-193, 2010.

165. Koutroubakis IE, Petinaki E, Dimoulios P, Vardas E, Roussomoustakaki M, Maniatis AN and Kouroumalis EA: Serum laminin and collagen IV in inflammatory bowel disease. J Clin Pathol 56: 817-820, 2003.

166. Spenlé C, Lefebvre O, Lacroute J, Méchine-Neuville A, Barreau F, Blottière HM, Duclos B, Arnold C, Hussenet T, Hemmerlé $\mathrm{J}$, et al: The laminin response in inflammatory bowel disease: Protection or malignancy? PLoS One 9: e111336, 2014.

167. de la Motte CA: Hyaluronan in intestinal homeostasis and inflammation: Implications for fibrosis. Am J Physiol Gastrointest Liver Physiol 301: G945-G949, 2011.

168. Sallam H, McNearney TA and Chen JD: Systematic review: Pathophysiology and management of gastrointestinal dysmotility in systemic sclerosis (scleroderma). Aliment Pharmacol Ther 23: 691-712, 2006

169. Sjogren RW: Gastrointestinal motility disorders in scleroderma. Arthritis Rheum 37: 1265-1282, 1994.

170. Marie I, Ducrotté P, Denis P, Hellot MF and Levesque H: Outcome of small-bowel motor impairment in systemic sclerosis-a prospective manometric 5-yr follow-up. Rheumatology (Oxford) 46: 150-153, 2007.

171. Greydanus MP and Camilleri M: Abnormal postcibal antral and small bowel motility due to neuropathy or myopathy in systemic sclerosis. Gastroenterology 96: 110-115, 1989. 
172. Iovino P, Valentini G, Ciacci C, De Luca A, Tremolaterra F, Sabbatini F, Tirri E and Mazzacca G: Proximal stomach function in systemic sclerosis: Relationship with autonomic nerve function. Dig Dis Sci 46: 723-730, 2001.

173. Ibba-Manneschi L, Del Rosso A, Pacini S, Tani A, Bechi P and Matucci Cerinic M: Ultrastructural study of the muscle coat of the gastric wall in a case of systemic sclerosis. Ann Rheum Dis 61: 754-756, 2002.

174. Manetti M, Neumann E, Milia AF, Tarner IH, Bechi P, Matucci-Cerinic M, Ibba-Manneschi L and Müller-Ladner U: Severe fibrosis and increased expression of fibrogenic cytokines in the gastric wall of systemic sclerosis patients. Arthritis Rheum 56: 3442-3447, 2007.

175. Pedersen J, Gao C, Egekvist H, Bjerring P, Arendt-Nielsen L, Gregersen $\mathrm{H}$ and Drewes AM: Pain and biomechanical responses to distention of the duodenum in patients with systemic sclerosis. Gastroenterology 124: 1230-1239, 2003.

176. Latella G, Di Gregorio J, Flati V, Rieder F and Lawrance IC: Mechanisms of initiation and progression of intestinal fibrosis in IBD. Scand J Gastroenterol 50: 53-65, 2015.

177. LeRoy EC, Trojanowska MI and Smith EA: Cytokines and human fibrosis. Eur Cytokine Netw 1: 215-219, 1990.

178. Babyatsky MW, Rossiter G and Podolsky DK: Expression of transforming growth factors alpha and beta in colonic mucosa in inflammatory bowel disease. Gastroenterology 110: 975-984, 1996.

179. Kulkarni AB and Karlsson S: Transforming growth factor-beta 1 knockout mice. A mutation in one cytokine gene causes a dramatic inflammatory disease. Am J Pathol 143: 3-9, 1993.

180. Gorelik L and Flavell RA: Transforming growth factor-beta in T-cell biology. Nat Rev Immunol 2: 46-53, 2002.
181. Meijer MJ, Mieremet-Ooms MA, van der Zon AM, van Duijn W, van Hogezand RA, Sier CF, Hommes DW, Lamers CB and Verspaget HW: Increased mucosal matrix metalloproteinase-1, $-2,-3$ and -9 activity in patients with inflammatory bowel disease and the relation with Crohn's disease phenotype. Dig Liver Dis 39: 733-739, 2007.

182. Lakatos G, Hritz I, Varga MZ, Juhász M, Miheller P, Cierny G, Tulassay $\mathrm{Z}$ and Herszényi L: The impact of matrix metalloproteinases and their tissue inhibitors in inflammatory bowel diseases. Dig Dis 30: 289-295, 2012.

183. Rath T, Roderfeld M, Graf J, Wagner S, Vehr AK, Dietrich C, Geier A and Roeb E: Enhanced expression of MMP-7 and MMP-13 in inflammatory bowel disease: A precancerous potential? Inflamm Bowel Dis 12: 1025-1035, 2006.

184. Booms P, Pregla R, Ney A, Barthel F, Reinhardt DP, Pletschacher A, Mundlos S and Robinson PN: RGD-containing fibrillin-1 fragments upregulate matrix metalloproteinase expression in cell culture: A potential factor in the pathogenesis of the Marfan syndrome. Hum Genet 116: 51-61, 2005.

185. Booms P, Ney A, Barthel F, Moroy G, Counsell D, Gille C, Guo G, Pregla R, Mundlos S, Alix AJ and Robinson PN: A fibrillin-1-fragment containing the elastin-binding-protein GxxPG consensus sequence upregulates matrix metalloproteinase-1: Biochemical and computational analysis. J Mol Cell Cardiol 40: 234-246, 2006. 